Article

\title{
Salicornia ramosissima Bioactive Composition and Safety: Eco-Friendly Extractions Approach (Microwave-Assisted Extraction vs. Conventional Maceration)
}

\author{
Ana Margarida Silva (D, João Pedro Lago, Diana Pinto, Manuela M. Moreira *(D, Clara Grosso *, \\ Virgínia Cruz Fernandes*(D), Cristina Delerue-Matos and Francisca Rodrigues *D
}

check for

updates

Citation: Silva, A.M.; Lago, J.P.; Pinto, D.; Moreira, M.M.; Grosso, C.; Cruz Fernandes, V.; Delerue-Matos,

C.; Rodrigues, F. Salicornia ramosissima Bioactive Composition and Safety: Eco-Friendly Extractions Approach (Microwave-Assisted Extraction vs. Conventional Maceration). Appl. Sci. 2021, 11, 4744. https://doi.org/ 10.3390/app11114744

Academic Editor: Piotr Latocha

Received: 30 April 2021

Accepted: 20 May 2021

Published: 21 May 2021

Publisher's Note: MDPI stays neutral with regard to jurisdictional claims in published maps and institutional affiliations.

Copyright: (C) 2021 by the authors Licensee MDPI, Basel, Switzerland. This article is an open access article distributed under the terms and conditions of the Creative Commons Attribution (CC BY) license (https:/ / creativecommons.org/licenses/by/ $4.0 /)$.
REQUIMTE/LAQV-Polytechnic of Porto-School of Engineering, Rua Dr. António Bernardino de Almeida, 431, 4249-015 Porto, Portugal; ana.silva@graq.isep.ipp.pt (A.M.S.); 14655410@colgaia.pt (J.P.L.);

diana.pinto@graq.isep.ipp.pt (D.P.); claragrosso@graq.isep.ipp.pt (C.D.-M.)

* Correspondence: manuela.moreira@graq.isep.ipp.pt (M.M.M.); clara.grosso@graq.isep.ipp.pt (C.G.); virginiacruz@graq.isep.ipp.pt (V.C.F.); francisca.rodrigues@graq.isep.ipp.pt (F.R.)

\begin{abstract}
Salicornia ramosissima J.Woods is an edible halophyte, widely distributed in the Portuguese salt marsh that has been under valorized. The aim of this study is to expand the knowledge regarding S. ramosissima bioactive composition and safety, highlighting its potential use as nutraceutical ingredient. Therefore, extracts obtained by conventional (CE) and microwave-assisted extraction (MAE) were characterized regarding phenolic profile, antioxidant activity, radical scavenging capacity and intestinal cell effects. Moreover, organic pesticides were screened to guarantee the consumers safety. The highest phenolic and flavonoid contents were observed for the $\mathrm{CE}$, as well as the scavenging capacity of $\mathrm{O}_{2}{ }^{\bullet-}\left(\mathrm{IC}_{50}=979.36 \mu \mathrm{g} / \mathrm{mL}\right)$ and $\mathrm{HOCl}\left(\mathrm{IC}_{50}=90.28 \mu \mathrm{g} / \mathrm{mL}\right)$. In contrast, the best antioxidant and antiradical activities were achieved by MAE $(65.56 \mu \mathrm{mol} \mathrm{FSE} / \mathrm{g} d w$ and $17.74 \mu \mathrm{g} \mathrm{AAE} / \mathrm{g}$ $\mathrm{dw}$ for FRAP and ABTS assays, respectively). The phenolic composition was similar for both extracts, being characterized by the presence of phenolic acids, flavonols, flavanols, flavones and flavanones. The predominant compound for both extracts was myricetin. None of the extracts were cytotoxic in intestinal cell lines. Vestigial levels of $\beta$-endosulfan and $\mathrm{p}, \mathrm{p}^{\prime}$-DDE were identified in MAE. These results support that $S$. ramosissima could be a source of bioactive compounds for nutraceutic industry.
\end{abstract}

Keywords: microwave-assisted extraction; conventional extraction; phenolic compounds; cytotoxicity; organochlorine pesticides

\section{Introduction}

Halophytes are salinity-sensitive plants species that grow in soils with high salt concentration (at least $200 \mathrm{mM} \mathrm{NaCl}$ ), being mainly found in salt marshes and coastal areas [1,2]. The saline environments are considered an abiotic local with constraints that may cause stress and affect plants morphology, physiology and biochemistry [3]. Nevertheless, halophytes recently arise has an alternative to conventional crops, promoting sustainable agriculture, particularly where water availability is scarce [4]. This is the case of Salicornia spp., a genus that has been used by humans for a long time, due to the gastronomic value [2]. Salicornia presents an extremely high salt tolerance and develops in crops with saline irrigation water [5]. For this reason, the mineral composition is diverse and the most abundant compounds are sodium, phosphate, calcium, phosphorus, magnesium, manganese, zinc and iron [4]. According to Essaidi et al., the principal fatty acids quantified in Salicornia europaea L. (syn. Salicornia herbacea L.) were palmitic and stearic acids [6]. Moreover, $S$. herbacea is considered a source of antioxidants such as phenolic acids (chlorogenic, ferulic, caffeic, salicylic and $p$-coumaric acids) and flavonoids (quercetin, kaempferol, hesperetin and galangin) [6]. Currently, some studies report that $S$. europaea present antioxidant, anti-inflammatory, anti-diabetic, or even anticancer properties $[7,8]$. 
The beneficial effects of $S$. herbacea uses on cosmetics, healthy food supplement and pharmaceutical applications were already highlighted [9]. Nevertheless, as stated, most of these studies were performed in S. europaea and little is known regarding S. ramosissima that is considered an alternative to salt and whose leaves are used for human diet [10]. The main applications of this species are in salads, canned or gourmet gastronomy $[4,10]$. S. ramosissima can be found in salt marshes at the coastline of Europe from the Arctic to the Mediterranean [2,11]. In Portugal, S. ramosissima is widely distributed in the salt marsh of Ria de Aveiro, being frequently used by the local population in cooking [12]. To the best of our knowledge, just two studies reported the extraction of bioactive compounds from S. ramosissima and none of them using water as solvent [2,4]. Barreira et al. compared the nutritional profile and the in vitro antioxidant activity of four edible halophytes, including S. ramosissima [4]. The authors used an UltraTurrax as extraction equipment and absolute ethanol $(1: 40, w / v)$ as solvent, and evaluated the total phenolic and flavonoid contents (TPC $=33.0 \mathrm{mg}$ of gallic acid equivalents (GAE) $/ \mathrm{g}$ dry weight $(\mathrm{dw})$ and TFC $=17.5 \mathrm{mg}$ of catechin equivalents (CAE)/g dw), as well as the antiradical activity by a DPPH assay $\left(\mathrm{IC}_{50}=5.69 \mathrm{mg} / \mathrm{mL}\right)$ [4]. More recently, Lima et al. screened the effect of different levels of salinity (ranging from 35 to $465 \mathrm{mM}$ of $\mathrm{NaCl}$ ) on the growth of S. ramosissima, as well as in the nutritional composition, antioxidant capacity and microbial quality [2]. The results revealed that plants cultivated between the lowest salinity and $200 \mathrm{mM}$ presented the highest amounts of phenolic compounds [2]. The authors reported that the TPC varied between 6.18 and $12.9 \mathrm{mg} \mathrm{GAE} / \mathrm{g} \mathrm{dw}$ and the TFC ranged from 0.15 to $0.37 \mathrm{mg}$ CAE/g $\mathrm{dw}$ [2]. The ABTS assay showed $\mathrm{IC}_{50}$ values ranging from 4.44 to $2.12 \mathrm{mg} / \mathrm{mL}$ of the extract [2].

Considering these achievements, the valorization of S. ramosissima may be a sustainable and environmental-friendly way to obtain extracts with interest for nutraceutical industry. Nevertheless, the extraction process is a key step to acquire bioactive compounds from plants, with emphasis on the extraction technique and solvent employed, which should maximize the extraction yield [13]. For a long time, extractions were only performed with conventional techniques, mostly using organic solvents, particularly harmful to the human health and the environment [14]. Besides that, traditional methods are associated with high solvents volumes and extraction times, generating large amount of wastes and low extraction yields [14]. Due to these drawbacks, sustainable extraction methodologies employing green solvents, such as microwave-assisted extraction (MAE), arise as alternatives. MAE is considered an easy, rapid and low-cost technique, presenting as main advantages a quick heating, a low solvent requirement and a clean processes [13]. The microwave heating principle is based on the effect of microwaves (with frequency between 0.3 to $300 \mathrm{GHz}$ ) on molecules by ionic conduction and dipole rotation [13,15,16]. Many studies reported that MAE can be successfully used to recover high-added value compounds from plants [17-19]. The objective of this study was to recover bioactive compounds from S. ramosissima by conventional extraction (maceration) and MAE using water as extractor solvent, aiming a new nutraceutical application. The TPC, TFC, antioxidant activity and in-vitro radical scavenging capacity were evaluated. Moreover, the characterization of phenolic composition as well as the in-vitro effects on intestinal cells and the presence of organic pesticides were screened.

\section{Materials and Methods}

\subsection{Chemicals}

Most of the chemical's reagents were acquired from Sigma-Aldrich (Steinheim, Germany). For HPLC analysis reference standards were purchased from Sigma-Aldrich (Sternheim, Germany) and all solvents employed were supplied by Merck (Darmstadt, Germany). Caco-2 clone type C2BBe1 and HT29-MTX cell lines were obtained from American Type Culture Collection (ATCC, USA), whereas Invitrogen Corporation (Life Technologies, S.A., Madrid, Spain) was the supplier of Dulbecco's Modified Eagle Medium (DMEM), Hank's Balanced Salt Solution (HBSS), Fetal Bovine Serum (FBS), non-essential amino acids, 
penicillin, streptomycin and trypsin-EDTA. Dimethylsulfoxide (DMSO) was supplied by AppliChem (Darmstadt, Germany).

A total of 14 organochlorine pesticides (OCPs) were selected for this study: $\alpha-, \beta-$, $\gamma$ - and $\delta$-hexachlorocyclohexanes (HCHs), hexachlorobenzene (HCB), o, $\mathrm{p}^{\prime}$-DDT ([1,1,1 trichloro-2, 2-bis-( p-chlorophenyl) ethane]), p, p'-DDE ([2,2bis( p-chlorophenyl)-1,1-dichloroethylene]), p, $\mathrm{p}^{\prime}$-DDD (dichlorodiphenyldichloro-ethane), aldrin, dieldrin, endrin, $\alpha$, $\beta$-endosulfan, and methoxychlor. Pesticide standards (purity $>97.0 \%$ ) were obtained from Chemservice (West Chester, PA, USA), Dr. Ehrenstorfer GmbH (Augsburg, Germany), and Sigma-Aldrich (Steinheim, Germany). Standard solutions of OCP were prepared in $n$-hexane (HPLC grade) supplied by Merck (Darmstadt, Germany). 4,40Dichlorobenzophenone was purchased from Sigma Aldrich (Steinheim, Germany) and used as an internal standard (IS) for chromatographic analysis. Methanol was supplied by Sigma Aldrich (Steinheim, Germany) and $n$-hexane purchased from Merck (Germany). Both solvents with purity over $99 \%$. Ultrapure water (resistivity of $18.2 \mathrm{M} \Omega . \mathrm{cm}$ ) was produced using a Simplicity 185 system (Millipore, Molsheim, France). $\mathrm{C}_{18} \mathrm{e}(200 \mathrm{mg}$ ) solid phase extraction (SPE) cartridges were provided by Phenomenex (Spain).

\subsection{Samples}

S. ramosissima J. Woods was collected during December 2019 in Ria de Aveiro costal lagoon, located at Esgueira, Cacia, Portugal (GPS coordinates: $40^{\circ} 39^{\prime} 56.3^{\prime \prime} \mathrm{N} 8^{\circ} 38^{\prime} 19.4^{\prime \prime} \mathrm{W}$ ). The identification was confirmed by the authors, following the characteristics described in Flora Ibérica [20]. Samples were dehydrated (Excalibur Food Dehydrator, Sacramento, CA, USA) at $41^{\circ} \mathrm{C}$ for $24 \mathrm{~h}$ and grinded in a miller (Moulinex A320) to obtain particles with $1 \mathrm{~mm}$ of size. Subsequently, samples were stored at $4{ }^{\circ} \mathrm{C}$ until further assays.

\subsection{Extraction Procedure}

The MAE was performed on a MARS-X 1500 W (Microwave Accelerated Reaction System for Extraction and Digestion, CEM, Mathews, NC, USA), according to the procedure described by Silva et al. [21]. Briefly, the dried powdered samples ( $300 \mathrm{mg})$ were mixed with water $(10 \mathrm{~mL})$. The MAE conditions employed were extraction time (5-10 min), extraction temperature $\left(72-94^{\circ} \mathrm{C}\right)$ and medium power $(300 \mathrm{~W})$ [21]. Afterwards, extracts were filtrated through a Whatman No. 1 filter paper and frozen at $-80^{\circ} \mathrm{C}$ for subsequent lyophilization (Telstar, model Cryodos -80 , Spain). After lyophilization, extracts were stocked at room temperature $\left(20^{\circ} \mathrm{C}\right)$ and kept in the dark.

For the conventional extracts (CE) a maceration was performed. Concisely, the sample $(300 \mathrm{mg})$ was added to boiling distilled water $(10 \mathrm{~mL})$ in a Becker and left boiling $\left(100^{\circ} \mathrm{C}\right)$ for $5 \mathrm{~min}$. After that time, the mixture was left for $25 \mathrm{~min}$, being then filtered, and lyophilized as described for microwave extracts.

\subsection{Determination of Total Phenolic and Flavonoids Contents (TPC and TFC)}

Total phenolic content (TPC) was measured spectrophotometrically according to the Folin-Ciocalteu procedure [22], with minor modifications [23]. Gallic acid was used as standard for the calibration curve (linearity range $\left.=5-100 \mu \mathrm{g} / \mathrm{mL} ; R^{2}>0.999\right)$. The results were expressed as milligrams of gallic acid equivalents (GAE) per gram of extract on dry weight (dw) (mg GAE/g dw).

Total flavonoid content (TFC) was performed using a colorimetric assay [24] and employing catechin as reference control (linearity range $=2.5-300 \mathrm{mg} / \mathrm{L} ; R^{2}>0.999$ ). TFC was expressed as milligrams of catechin equivalents (CAE) per gram of extract on dw (mg $\mathrm{CE} / \mathrm{g} \mathrm{dw})$.

\subsection{HPLC-PDA Analysis}

The phenolic composition of $S$. ramosissima extracts obtained by $C E$ and MAE were carried out by HPLC-PDA, following the procedure described by Moreira et al. [17]. This analysis was performed on a Shimadzu HPLC system (Shimadzu Corporation, Kyoto, 
Japan) with photodiode array (PDA) equipped with a Gemini $\mathrm{C}_{18}$ column $(250 \mathrm{~mm} \times$ $4.6 \mathrm{~mm}, 5 \mu \mathrm{m}$, Phenomenex, Alcobendas, Spain) at $25{ }^{\circ} \mathrm{C}$. The stock standards were prepared with a mixture of methanol:water $(50: 50, v / v)$ in order to obtain the calibration curves $(1-200 \mathrm{mg} / \mathrm{L})$. The mobile phase was composed of methanol (A) and water (B), both with $0.1 \%$ formic acid at a flow rate of $1.0 \mathrm{~mL} / \mathrm{min}$ The identification of the phenolic compounds was performed by comparing the UV absorption spectra and the retention time of each compound with those of pure standards injected under the same conditions. According to their maximum wavelength, the compounds were quantified at $280 \mathrm{~nm}$, $320 \mathrm{~nm}$ and $360 \mathrm{~nm}$ using the calibration curves from the respective standard. Relevant analytical data, namely regression equations, limit of detection (LOD) and quantification (LOQ), are shown in Table S1 (Supplementary Material). The content of individual phenolic compounds identified in each extract was expressed as $\mathrm{mg}$ of compound per gram of extract on $\mathrm{dw}$ (mg compound/g dw).

\subsection{In-Vitro Antioxidant and Antiradical Activities \\ 2.6.1. Ferric Reducing Antioxidant Power (FRAP) Assay}

The FRAP assay was performed according to Benzie and Strain [25], with minor modifications [23]. The calibration curve was prepared with a solution of ferrous sulphate $\left(\mathrm{FeSO}_{4} \cdot 7 \mathrm{H}_{2} \mathrm{O}\right) 1 \mathrm{mM}$ (linearity range: $\left.25-500 \mu \mathrm{M} ; R^{2}>0.999\right)$. The results were expressed in $\mu \mathrm{M}$ ferrous sulphate equivalents (FSE) per gram of extract on dw ( $\mu \mathrm{M} \mathrm{FSE} / \mathrm{g} \mathrm{dw}$ ).

\subsubsection{ABTS Radical Scavenging Activity Assay}

The ABTS radical scavenging activity was evaluated according to Re et al. [26], with minor modifications. Ascorbic acid was prepared as standard for calibration curve (linearity range: $\left.5-75 \mu \mathrm{g} / \mathrm{mL} ; R^{2}>0.994\right)$. The results were expressed in $\mu$ g ascorbic acid equivalents (AAE) per gram of extract on $\mathrm{dw}(\mu \mathrm{g} \mathrm{AAE} / \mathrm{g} \mathrm{dw})$.

\subsection{Reactive Species Scavenging Capacities}

A Synergy HT Microplate Reader (BioTek Instruments, Inc., Winooski, VT, USA) equipped with a thermostat and capable to measurer fluorescence and UV/Vis, was employed to evaluate the reactive species scavenging capacity. Standards and samples were prepared according to described Pinto et al. [27]. Catechin and gallic acid were used as positive controls. The results were expressed in $\mathrm{IC}_{50}$ values (concentration required to obtain an inhibition capacity of 50\%).

\subsubsection{Superoxide Radical Scavenging Assay}

The scavenging activities of $S$. ramosissima extracts against superoxide anion radical $\left(\mathrm{O}_{2}{ }^{\bullet-}\right)$ were evaluated according to Gomes et al. [28]. This colorimetric assay is based on the reduction of NBT into a purple colored diformazan as result of the reaction with $\mathrm{O}_{2}{ }^{\bullet-}$. Results were expressed as the inhibition, in $\mathrm{IC}_{50}$, of the NBT reduction to diformazan.

\subsubsection{Hypochlorous Acid Scavenging Assay}

The hypochlorous acid $(\mathrm{HOCl})$ assay was based on a fluorescent methodology, as previously described by Gomes et al. [28]. The positive controls used were catechin and gallic acid. Results were expressed as the inhibition, in $\mathrm{IC}_{50}$, of $\mathrm{HOCl}$-induced oxidation of dihydrorhodamine 123 (DHR).

\subsubsection{Peroxyl Radical Scavenging Assay}

The peroxyl radical (ROO•) scavenging assay, also denominated as the oxygen radical absorbance capacity (ORAC) assay, was evaluated following the methodology of Ou et al. [29]. Trolox was used as standard control and the results were expressed as $\mu \mathrm{mol}$ of Trolox equivalents (TE) per milligram of extract on dry weight ( $\mu \mathrm{mol} \mathrm{TE} / \mathrm{mg} \mathrm{dw}$ ). 


\subsection{Cell Viability Assays}

Two different intestinal cell lines (Caco-2 (passage 63-64) and HT29-MTX (passage 50-51)) were employed to screen the viability through a 3-(4,5-dimethylthiazol-2-yl)-2,5diphenyltetrazolium bromide (MTT) assay. According to Francisco et al. [30], cells were incubated during $24 \mathrm{~h}$ at $37^{\circ} \mathrm{C}$ with fresh medium in the absence or presence of $\mathrm{S}$. ramosissima extracts (concentrations varied between 0.1 and $1000 \mu \mathrm{g} / \mathrm{mL}$ ). DMEM and Triton $\mathrm{X}-1001 \%(w / v)$ were used as positive and negative controls, respectively. The results were expressed as percentages of cell viability.

\subsection{Detection of Organochlorine Pesticides}

S. ramosissima extracts were diluted with ultrapure water (1:2) and passed through the SPE $\mathrm{C}_{18}$ e cartridge, which was previously conditioned with the elution solvent ( $n$-hexane) followed by methanol and ultrapure water $(2 \times 2 \mathrm{~mL}$ of each). After the concentration step, cartridges were rinsed with $5 \mathrm{~mL}$ of ultrapure water, dried for $10 \mathrm{~min}$, and eluted with $2 \times 2 \mathrm{~mL} n$-hexane. This extract was dried using a gentle stream of nitrogen and recovered in $1 \mathrm{~mL}$ of $n$-hexane before injection in the chromatographic system. The gas chromatography analyses were performed according to Fernandes et al. [31].

\subsection{Statistical Analysis}

Data were expressed as mean \pm standard deviation of at least three independent experiments $(n=3)$ carried out for each one of the three batches of extracts. The statistical analyses were performed using IBM SPSS Statistics 24.0 software (SPSS Inc., Chicago, IL, USA). One-way ANOVA was employed to investigate the differences between extracts, whilst Tukey's HSD test was performed for post hoc comparisons of the means. A denoting significance was accepted for $p$ values lower than $0.05(p<0.05)$.

\section{Results and Discussion}

\subsection{TPC, TFC and Antioxidant/Antiradical Activities}

The TPC, TFC, antioxidant/antiradical activities and extraction yield of the extracts obtained by CE and MAE are summarized in Table 1.

Table 1. Extraction yield, total phenolic and flavonoid contents (TPC and TFC, respectively), and in vitro antioxidant/antiradical activities (evaluated by FRAP, ABTS and DPPH assays) of $S$. ramosissima extracts prepared by conventional and microwave-assisted extraction (CE and MAE, respectively). Values are expressed as mean \pm standard deviation $(n=3)$.

\begin{tabular}{ccccccc}
\hline $\begin{array}{c}\text { Extraction } \\
\text { Techniques }\end{array}$ & $\begin{array}{c}\text { Extraction Yield } \\
\mathbf{( \% )}\end{array}$ & $\begin{array}{c}\text { TPC } \\
\text { (mg GAE/g dw) }\end{array}$ & $\begin{array}{c}\text { TFC } \\
\text { (mg CAE/g dw) }\end{array}$ & $\begin{array}{c}\text { FRAP } \\
(\boldsymbol{\mu m o l ~ F S E / g ~ d w ) ~}\end{array}$ & $\begin{array}{c}\text { ABTS } \\
(\boldsymbol{\mu} \mathbf{g} \text { AAE/g dw) }\end{array}$ \\
\hline CE & $21.14 \pm 1.32$ & $15.02 \pm 2.01 *$ & $8.44 \pm 0.45$ & $60.61 \pm 6.64$ & $15.55 \pm 0.78$ \\
MAE & $26.10 \pm 2.07$ & $8.34 \pm 1.22$ & $8.41 \pm 0.45$ & $65.56 \pm 8.68$ & $17.74 \pm 2.95 *$ \\
\hline
\end{tabular}

${ }^{*}$ Indicate significant differences between extracts $(p<0.05)$.

The extraction yield ranged between $21.14 \%$ and $26.10 \%$ for CE and MAE extracts, respectively. These results are higher than the ones reported by Medini et al. for the halophyte Limonium densiflorum extracts that were prepared by Soxhlet extraction with hexane (10.33\%), dichloromethane (6.66\%), methanol (18.00\%), and ethanol (11.06\%) [32].

The TPC obtained were, respectively, 15.02 and $8.34 \mathrm{mg} \mathrm{GAE} / \mathrm{g} \mathrm{dw}$ for CE and MAE extracts $(p<0.01)$. These results were in line with Lima et al. that evaluated the antioxidant activity of $S$. ramosissima with different levels of salinity extracted using $80 \%$ of acetone $(1: 40, w / v)$ [2]. According to the authors, the TPC ranged between 6.18 and $12.9 \mathrm{mg}$ $\mathrm{GAE} / \mathrm{g} \mathrm{dw}$, being the highest value described for the S. ramosissima cultivated in $200 \mathrm{mM}$ of salinity [2]. In another study, Barreira et al. reported a TPC of $33.00 \mathrm{mg}$ GAE/g dw for the ethanolic extracts $(1: 40, w / v)$ of $S$. ramosissima, being higher than the one obtained in the present work [4]. However, the authors used ethanol as solvent, which may lead to the 
extraction of different compounds. Besides, many abiotic/biotic factors may also influence the level of secondary metabolites present in halophytes [33].

In what concerns TFC, both extracts shown similar values, respectively, $8.44 \mathrm{mg}$ $\mathrm{CAE} / \mathrm{g} \mathrm{dw}$ and and $8.41 \mathrm{mg} \mathrm{CAE} / \mathrm{g} \mathrm{dw}$, for the $\mathrm{CE}$ and the MAE extracts. No significant differences $(p<0.05)$ between them were observed. Lima et al. also analyzed the TFC of S. ramosissima, but the values reported were lower than those reported in Table 1 , ranging from 0.15 to $0.50 \mathrm{mg} \mathrm{CAE} / \mathrm{g} \mathrm{dw}$ [2]. However, Barreira et al. obtained a highest TFC result (17.50 mg CAE/g dw) for the alcoholic extract [4]. As previously mentioned, these values may be due not only to the solvent employed, but also to the extraction time and temperature used during extraction [34].

The capacity of $S$. ramosissima extracts to reduce ferric ions were evaluated by FRAP assay and revealed that MAE extract exhibited the highest value $(65.56 \mu \mathrm{mol} \mathrm{FSE} / \mathrm{g} \mathrm{dw})$ and the CE extract the lowest $(60.61 \mu \mathrm{mol} \mathrm{FSE} / \mathrm{g} \mathrm{dw})$, without significant differences $(p>0.05)$. Costa et al. analysed the antioxidant activity of Crithmum maritimum L. and S. europaea extracts obtained by ultrasound-assisted extraction (UAE) and supercritical fluid extraction (SFE) using different concentrations of ethanol [35]. According to the authors, the antioxidant activity of S. europaea UAE extracts, evaluated by the same assay, ranged between 27.4 and $180.2 \mu \mathrm{mol} \mathrm{FSE} / \mathrm{g} \mathrm{dw}$, with the lowest result being described for the extraction with $100 \%$ of ethanol and the highest for the extract obtained with $80 \%$ of ethanol. For the SFE extracts, Costa et al. obtained lower values (5.22, 10.22 and $10.38 \mu \mathrm{mol}$ FSE/g dw, respectively, for the extractions with $10 \%, 20 \%$ and $40 \%$ of ethanol).

In what concerns to the ABTS assay, the MAE presented the best result $(17.74 \mu \mathrm{g}$ $\mathrm{AAE} / \mathrm{g} \mathrm{dw})$, while the CE showed the worst (15.55 $\mu \mathrm{g}$ AAE/g dw). Significant differences $(p<0.05)$ were observed between extracts. Costa et al. also evaluated the ABTS scavenging capacity for the different extracts of S. europaea [35]. For the UAE extract, the authors reported that values varied between 4.5 and $22.8 \mathrm{mg} \mathrm{TE} / \mathrm{g} \mathrm{dw}$, respectively, for the extraction with $100 \%$ and $40 \%$ of ethanol, while the highest result for the SFE extraction was obtained with $40 \%$ of ethanol $(1.33 \mathrm{mg} \mathrm{TE} / \mathrm{g} \mathrm{dw})$. In another study, Lima et al. reported a greater capacity of $S$. ramosissima cultivated with six different salinities to scavenge ABTS [2]. The $\mathrm{IC}_{50}$ values ranged between 2.12 and $4.44 \mathrm{mg} / \mathrm{mL}$, being higher than those presented in Table 1.

The possible correlation between antioxidant/antiradical activities (FRAP and ABTS assays) and the TPC and TFC results was evaluated by a Pearson correlation for both extracts. Regarding the $\mathrm{CE}$, a weak positive correlation was observed between the TFC and FRAP $\left(r^{2}=0.0982 ; p<0.05\right)$ as well as between TPC and FRAP $\left(r^{2}=0.0878 ; p<0.05\right)$ and TPC and ABTS $\left(r^{2}=0.1330 ; p<0.05\right)$. Weak negative correlations were also observed between TFC and ABTS $\left(r^{2}=-0.0484 ; p<0.05\right)$ and ABTS and FRAP $\left(r^{2}=-0.5292\right.$; $p<0.05)$. Nevertheless, a strong positive correlation was observed between TPC and TFC $\left(r^{2}=0.7312 ; p<0.05\right)$, demonstrating that flavonoids are probably the most predominant phenolic compounds.

Similar results were achieved for the MAE extract, being determined again a strong positive correlation between TPC and TFC $\left(r^{2}=0.7134 ; p<0.05\right)$. Once again, the correlations between TFC and ABTS $\left(r^{2}=-0.3059 ; p<0.05\right)$, TFC and FRAP $\left(r^{2}=-0.0746\right.$; $p<0.05)$, ABTS and FRAP $\left(r^{2}=-0.5886 ; p<0.05\right)$ and TPC and FRAP $\left(r^{2}=-0.1865\right.$; $p<0.05)$ were negative. Besides that, a strong negative correlation between TPC and ABTS $\left(r^{2}=-0.8024 ; p<0.05\right)$ should be highlighted. Considering the correlation of Pearson for this extract, it is possible to infer that flavonoid are probably the phenolic compounds present in highest amounts, as further demonstrated by the identification and quantification of phenolic compounds by HPLC-PDA.

Nevertheless, it should be resalted that the spectrophotometric assays employed may present some drawbacks, such as quantification methods, reaction kinetics and, most importantly, interferences that could result of the presence of different compounds such as sugars, aromatic amines and ascorbic acid $[24,30]$. 


\subsection{Identification and Quantification of Phenolic Compounds by HPLC-PDA}

HPLC-PDA was employed to identify and quantify the individual phenolic compounds of $S$. ramosissima extracts (Figure 1). Table 2 summarizes the different phenolic compounds identified and quantified.
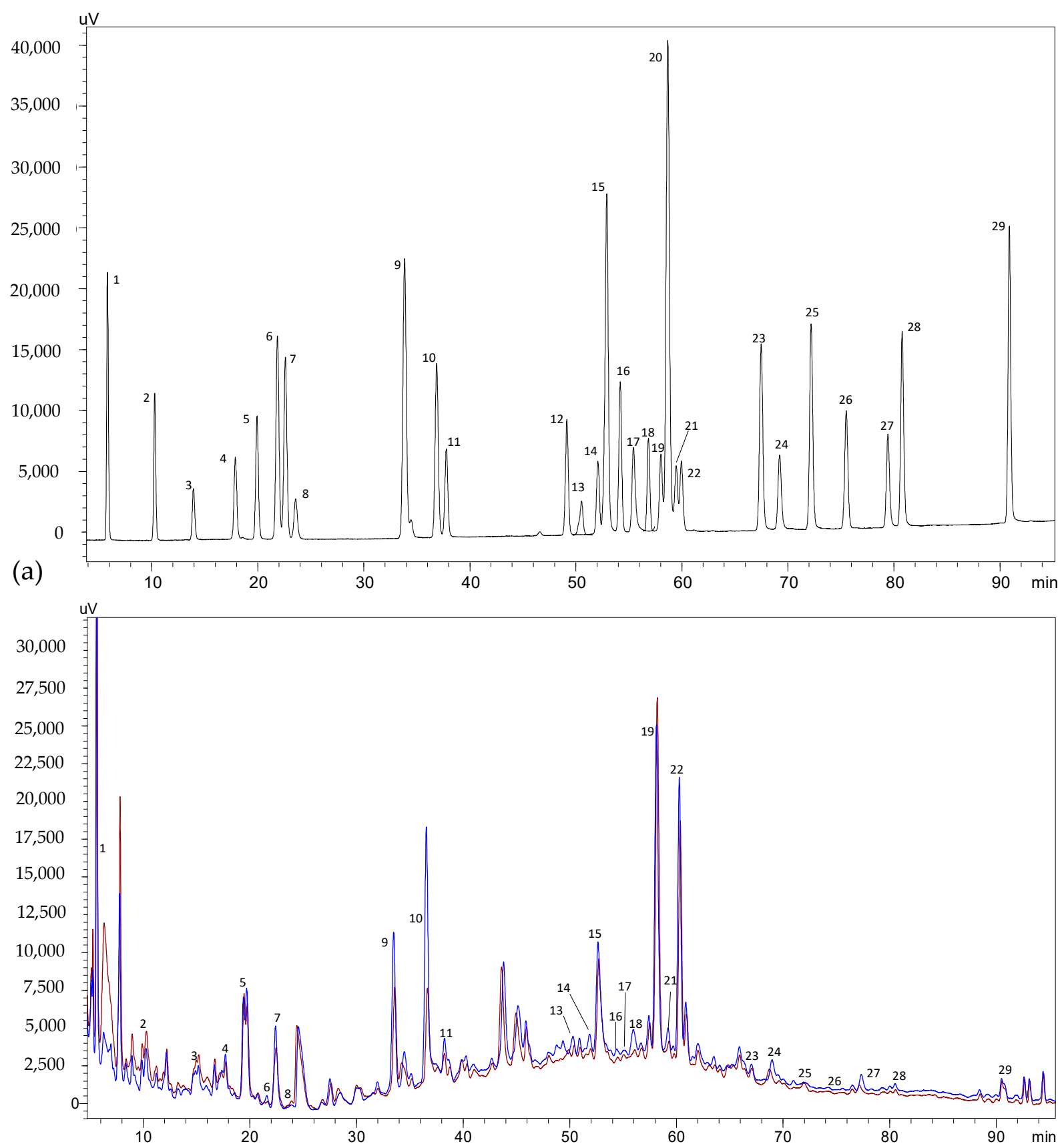

(b)

Figure 1. HPLC-PDA chromatogram monitored at $280 \mathrm{~nm}$ for (a) polyphenol standard mixture of $5 \mathrm{mg} / \mathrm{L}$ and for (b) salicornia extract (blue and brown lines correspond to CE and MAE extracts, respectively); peak identification: (1) gallic acid, (2) protocatechuic acid, (3) (+)-catechin, (4) chlorogenic acid, (5) vanillic acid, (6) caffeic acid, (7) syringic acid, (8) (-)-epicatechin, (9) p-coumaric acid, (10) trans-ferulic acid, (11) sinapic acid, (12) naringin, (13) 3,5-di-O-caffeoylquinic acid, (14) quercetin-3-O-galactoside, (15) rutin, (16) phloridzin, (17) ellagic acid, (18) 3,4-di-O-caffeoylquinic acid; (19) myricetin, (20) cinnamic acid, (21) kaempferol-3-O-glucoside, (22) kaempferol-3-O-rutinoside, (23) naringenin, (24) quercetin, (25) phloretin, (26) tiliroside, (27) kaempferol, (28) apigenin and (29) chrysin. 
Table 2. Content of the identified phenolic compounds in S. ramosissima extracts prepared by CE and MAE. Results were expressed as mean \pm standard deviations (mg of compound/g dw).

\begin{tabular}{|c|c|c|}
\hline Compounds & $\begin{array}{c}C E \\
(m g / g d w)\end{array}$ & $\begin{array}{c}\text { MAE } \\
(\mathrm{mg} / \mathrm{g} d w)\end{array}$ \\
\hline \multicolumn{3}{|l|}{ Phenolic acids } \\
\hline Gallic acid & $0.2105 \pm 0.0105$ & $0.1553 \pm 0.0078$ \\
\hline Protocatechuic acid & $0.1275 \pm 0.0064$ & $0.0929 \pm 0.0046$ \\
\hline Chlorogenic acid & $0.0758 \pm 0.0038$ & $0.0342 \pm 0.0017$ \\
\hline Vanillic acid & $0.0984 \pm 0.0049$ & $0.0615 \pm 0.0031$ \\
\hline Caffeic acid & $0.0144 \pm 0.0007$ & $0.0032 \pm 0.0002$ \\
\hline Syringic acid & $0.0498 \pm 0.0025$ & $0.0335 \pm 0.0017$ \\
\hline$p$-coumaric acid & $0.0483 \pm 0.0024$ & $0.0349 \pm 0.0017$ \\
\hline Ferulic acid & $0.1346 \pm 0.0067$ & $0.0578 \pm 0.0029$ \\
\hline Sinapic acid & $0.0293 \pm 0.0015$ & $0.0216 \pm 0.0011$ \\
\hline 3,5-di-O-caffeoylquinic acid & $0.0259 \pm 0.0013$ & $0.0280 \pm 0.0014$ \\
\hline 3,4-di-O-caffeoylquinic acid & $0.0646 \pm 0.0032$ & $0.0355 \pm 0.0018$ \\
\hline Ellagic acid & $0.0381 \pm 0.0019$ & $0.0258 \pm 0.0013$ \\
\hline Cinnamic acid & ND & ND \\
\hline$\sum$ Phenolic acids & $0.9173 \pm 0.0458$ & $0.5842 \pm 0.0293$ \\
\hline \multicolumn{3}{|l|}{ Flavanols } \\
\hline Catechin & $0.1116 \pm 0.0056$ & $0.0046 \pm 0.0002$ \\
\hline Epicatechin & $0.0102 \pm 0.0005$ & $0.0011 \pm 0.0001$ \\
\hline$\sum$ Flavanols & $0.1218 \pm 0.0061$ & $0.0056 \pm 0.0003$ \\
\hline \multicolumn{3}{|l|}{ Flavanones } \\
\hline Naringin & ND & $0.0124 \pm 0.0006$ \\
\hline Naringenin & ND & $0.0076 \pm 0.0004$ \\
\hline$\sum$ Flavanones & 0 & $0.0199 \pm 0.0010$ \\
\hline \multicolumn{3}{|l|}{ Flavonols } \\
\hline Rutin & $0.0999 \pm 0.0050$ & $0.0781 \pm 0.0039$ \\
\hline Quercetin-3-O-galactoside & $0.0598 \pm 0.0030$ & $0.0454 \pm 0.0023$ \\
\hline Myricetin & $0.4250 \pm 0.0213$ & $0.4655 \pm 0.0233$ \\
\hline Kaempferol-3-O-glucoside & $0.0806 \pm 0.0040$ & $0.0771 \pm 0.0039$ \\
\hline Kaempferol-3-O-rutinoside & $0.0263 \pm 0.0013$ & $0.0240 \pm 0.0012$ \\
\hline Quercetin & $0.0340 \pm 0.0017$ & $0.0284 \pm 0.0014$ \\
\hline Tiliroside & $0.0020 \pm 0.0001$ & $0.0031 \pm 0.0002$ \\
\hline Kaempferol & $0.0052 \pm 0.0003$ & $0.0047 \pm 0.0002$ \\
\hline$\sum$ Flavonols & $0.7329 \pm 0.0367$ & $0.7264 \pm 0.0364$ \\
\hline \multicolumn{3}{|l|}{ Flavones } \\
\hline Apigenin & $0.0045 \pm 0.0002$ & $0.0034 \pm 0.0002$ \\
\hline Chrysin & $0.0042 \pm 0.0002$ & $0.0035 \pm 0.0002$ \\
\hline$\sum$ Flavones & $0.0087 \pm 0.0004$ & $0.0069 \pm 0.0004$ \\
\hline \multicolumn{3}{|l|}{ Others } \\
\hline Phloridzin & $0.0205 \pm 0.0010$ & $0.0178 \pm 0.0009$ \\
\hline Phloretin & ND & $0.0032 \pm 0.0002$ \\
\hline$\sum$ Others & $0.0205 \pm 0.0010$ & $0.0210 \pm 0.0011$ \\
\hline
\end{tabular}

ND: not detected.

According to Table 2, the total amount of phenolic compounds identified and quantified in both extracts were similar. Phenolic acids and flavonols are the principal constituents of the $\mathrm{CE}$, being responsible of $50 \%$ and $40 \%$ of the total phenolic composition, respectively. On the other hand, flavonols are present in highest concentration in MAE, followed by phenolic acids ( $53 \%$ and $43 \%$, respectively). For both extracts, myricetin was the compound present in highest amounts ( 0.4250 and $0.4655 \mathrm{mg}$ myricetin/g dw for CE and MAE extracts, respectively). Myricetin is a flavonoid well known by its benefits for human health that are based on different pharmacological activities, such as antioxidant, anti-inflammatory, anti- 
cancer, or even immunomodulatory activities, among others [36-38]. Recently, Park et al. demonstrated in-vivo the antiproliferative effects of myricetin on endometriosis through cell cycle regulation [39].

Regarding phenolic acids, gallic acid was the major compound in both extracts $(0.2105$ and $0.1553 \mathrm{mg}$ gallic acid/g dw, respectively). Catechin and epicatechin were the two flavanols identified and quantified, but CE showed the highest values $(0.1116 \mathrm{mg}$ catechin/g dw and $0.0102 \mathrm{mg}$ epicatechin/g dw). Naringin $(0.0124 \mathrm{mg} / \mathrm{g} \mathrm{dw})$ and naringenin $(0.0076 \mathrm{mg} / \mathrm{g} \mathrm{dw})$ were only identified and quantified in MAE. Rutin, kaempferol-3-Oglucoside and quercetin-3-O-galactoside were the principal flavonols quantified. Apigenin was the flavone found in high amount, with $\mathrm{CE}$ extract exhibiting the highest result $(0.0045 \mathrm{mg} / \mathrm{g} \mathrm{dw})$.

To the best of our knowledge, this is the first study that analyzed the phenolic profile of S. ramosissima. Zengin et al. studied the phenolic compounds of three halophyte species, including S. europaea, through LC-MS/MS analysis [40]. The authors identified and quantified 11 compounds in the methanolic extract of S. europaea. The principal compound reported was rosmarinic acid $(346.41 \mu \mathrm{g} / \mathrm{g}$ extract), followed by quinic acid $(116.7 \mu \mathrm{g} / \mathrm{g}$ extract). Gallic acid was the compound present in lower amounts $(4.24 \mu \mathrm{g} / \mathrm{g}$ extract), being this value inferior to the one reported in our study. Bertin et al. characterized by HPLC-ESI-MS/MS two extracts of Sarcocornia ambigua, a plant similar to S. ramosissima, with different growing conditions [41]. The authors reported the presence of phenolic acids and flavonoids, being ferulic, caffeic, vanillic, $p$-coumaric acids, kaempferol and galangin the principal compounds.

\subsection{In-Vitro Scavenging Capacity of Reactive Species}

Halophytes are characterized by the presence of a complex antioxidant defense mechanism, involving enzymatic and non-enzymatic pathways, that maintain the plant homeostasis between reactive species, antioxidants and cell signaling [42]. Considering that, the reactive oxygen species (ROS) scavenging by $S$. ramosissima extracts were evaluated (Table 3).

Table 3. Superoxide anion radical $\left(\mathrm{O}_{2}^{\bullet-}\right)$, hypochlorous acid $(\mathrm{HOCl})$, and peroxyl radical $(\mathrm{ROO} \bullet)$ scavenging capacities of $S$. ramosissima extracts obtained by CE and MAE. Different letters $(a, b, c)$ in the same column mean significant differences $(p<0.05)$ between different extracts.

\begin{tabular}{|c|c|c|c|}
\hline & \multicolumn{3}{|c|}{ ROS } \\
\hline & $\mathrm{O} 2^{\bullet-}$ & $\mathrm{HOCl}$ & ROO• \\
\hline & \multicolumn{2}{|c|}{$\mathrm{IC}_{50}(\mu \mathrm{g} / \mathrm{mL})$} & $\mu \mathrm{mol} \mathrm{TE} / \mathrm{mg} \mathrm{dw}$ \\
\hline \multicolumn{4}{|c|}{ S. ramosissima extracts } \\
\hline $\mathrm{CE}$ & $979.36 \pm 4.66^{\mathrm{c}}$ & $90.28 \pm 8.54^{c}$ & $0.056 \pm 0.011^{c}$ \\
\hline MAE & NA & $104.64 \pm 2.06^{\mathrm{c}}$ & $0.061 \pm 0.009^{c}$ \\
\hline \multicolumn{4}{|c|}{ Positive controls } \\
\hline Catechin & $123.78 \pm 0.28^{b}$ & $0.96 \pm 0.04^{\mathrm{a}}$ & $3.217 \pm 0.116^{b}$ \\
\hline Gallic acid & $101.37 \pm 1.18^{\mathrm{a}}$ & $11.76 \pm 0.29^{b}$ & $38.215 \pm 2.180^{a}$ \\
\hline
\end{tabular}

NA-no activity.

The first step of oxygen reduction is the formation of superoxide anion radical $\left(\mathrm{O}_{2}{ }^{\bullet-}\right)$, that is converted to hydrogen peroxide $\left(\mathrm{H}_{2} \mathrm{O}_{2}\right)$ by superoxide dismutase (SOD) [42]. $\mathrm{O}_{2}^{\bullet-}$ and $\mathrm{H}_{2} \mathrm{O}_{2}$ are the precursors of others ROS with toxic effects. According to Table 3, CE shown the best capacity to scavenge $\mathrm{O}_{2}{ }^{\bullet-}$, presenting an $\mathrm{IC}_{50}=979.36 \mu \mathrm{g} / \mathrm{mL}$. However, it was impossible to determine the $\mathrm{IC}_{50}$ for the highest concentration of MAE extract tested $(1000 \mu \mathrm{g} / \mathrm{mL})$, exhibiting an inhibition of $39.76 \%$. Catechin and gallic acid showed better values comparatively with $S$. ramosissima extracts. Significant differences $(p<0.05)$ were observed between the positive controls and the CE extract. Despite the observed differences, our results may be due to the extracts rich composition in flavonoids, since compounds such as quercetin, myricetin and rutin are considered effective inhibitors 
of $\mathrm{O}_{2}{ }^{\bullet-}$ [43]. Further, the obtained activities are also lower than the ones reported by Daffodil for the petroleum ether, benzene, ethyl acetate, methanol and ethanol extracts of $S$. brachiata against $\mathrm{O}_{2}{ }^{\bullet-}$ [44]. The $\mathrm{IC}_{50}$ values obtained ranged between $19.14 \mu \mathrm{g} / \mathrm{mL}$ and $28.64 \mu \mathrm{g} / \mathrm{mL}$, respectively for the ethyl acetate and methanol extracts [44]. These differences may be due to the extraction technique and solvents employed; nevertheless, most of the solvents employed by these authors were toxic, while in the present study water, a green and safe solvent, was used.

$\mathrm{HOCl}$ is a $\mathrm{ROS}$ generated in the presence of $\mathrm{O}_{2}{ }^{\bullet-}$, being particularly reactive during inflammatory processes [34]. Both extracts showed a good scavenging capacity of $\mathrm{HOCl}$, with $\mathrm{IC}_{50}$ values of $90.28 \mu \mathrm{g} / \mathrm{mL}$ and $104.64 \mu \mathrm{g} / \mathrm{mL}$ for CE and MAE, respectively. Nevertheless, the values obtained for S. ramosissima extracts were higher than the positive controls $(p<0.05)$.

The peroxyl radical (ROO`) is an important chain-carrying species in the reaction of organic compounds with molecular oxygen, and its scavenging prevents lipid peroxidation $[45,46]$. As shown in Table 3 , the results obtained for the extracts were very similar (0.056 and $0.061 \mu \mathrm{mol} \mathrm{TE} / \mathrm{mg} \mathrm{dw}$ for CE and MAE, respectively) and no significant differences $(p>0.05)$ were found. Nevertheless, the standards showed a higher scavenging activity against $\mathrm{ROO}^{\bullet}$, being gallic acid the best compound $(38.215 \mu \mathrm{mol} \mathrm{TE} / \mathrm{mg} \mathrm{dw})$. Significant differences $(p<0.05)$ were observed between standards as well as between each standard and the different extracts. Souid et al. performed an ORAC assay to evaluated the antioxidant activity of the halophyte plant Limonium delicatulum (Girard) Kuntze in its salty natural habitat during one year [47]. The extracts were prepared with $80 \%$ $(v / v)$ methanol [47]. According to the authors, the results varied between 2264.26 and $5792.66 \mu \mathrm{mol} \mathrm{TE} / \mathrm{mg} \mathrm{dw}$, corresponding the lowest activity to February and the highest to August [47]. These results were positively influenced by the dry period of the year, that lead to high levels of polyphenols in order to grant protection against the oxidative stress caused by the high salinity [47]. In another study, Oueslati et al. evaluated the antioxidant capacity through ORAC method of four extracts (hexane, dichloromethane, methanol and water) of the halophyte Suaeda fruticosa Forssk. ex J.F.Gmel. [48]. The methanolic extract showed the highest result $(2.94 \mu \mathrm{mol} \mathrm{TE} / \mathrm{mg} \mathrm{dw})$, while the hexane extract was the worst $(0.11 \mu \mathrm{mol} \mathrm{TE} / \mathrm{mg} \mathrm{dw})$ [48]. Nonetheless, the L. delicatulum and S. fruticosa showed a higher ability to quench $\mathrm{ROO}^{\bullet}$ than the $S$. ramosissima extracts.

\subsection{Effects of Extracts towards Caco-2 and HT29-MTX Cells}

The MTT assay is a colorimetrical assay traditionally employed to determine the cell viability through reduction of the tetrazolium salt to a formazan salt [49]. Figure 2 presents the cell viability results of Caco-2 and HT29-MTX after exposure to the S. ramosissima extracts.

The HT29-MTX viability did not decrease after exposure to the different extracts' concentrations. At the highest concentration tested $(1000 \mu \mathrm{g} / \mathrm{mL})$, the viability was $97.04 \%$ and $94.32 \%$, respectively, for the CE for MAE extracts. On the other hand, none of the CE concentrations led to a decrease of Caco-2 viability at concentrations up to $1000 \mu \mathrm{g} / \mathrm{mL}$. However, after exposure to the highest concentration of MAE $(1000 \mu \mathrm{g} / \mathrm{mL})$, the viability of Caco-2 decreased to $86.55 \%$. Nevertheless, no significant differences $(p>0.05)$ were observed between the different concentrations of each extract in both cell lines. Considering these results, it is possible to affirm that the $\mathrm{IC}_{50}$ for Caco-2 and HT29-MTX is higher than $1000 \mu \mathrm{g} / \mathrm{mL}$.

To the best of our knowledge, this is the first study that evaluates the effects of $S$. ramosissima extract on the viability of intestinal cell lines. Kang et al. screened the cytotoxic effects of S. herbacea seeds (prepared firstly with $70 \%$ methanol on a hot plate at $60{ }^{\circ} \mathrm{C}$ for $2 \mathrm{~h}$ and then with series of solvent fractions (hexane, ethyl ether, ethyl acetate, and water)) in HT29 colon cancer cells [7]. According to the authors, the extract prepared with water did not show inhibitory effects on the cells viability; however, for the different solvents fractions, a high cytotoxicity was reported $\left(\mathrm{IC}_{50}=50.4 \mu \mathrm{g} / \mathrm{mL}\right.$ for ethyl ether fraction and around $90 \mu \mathrm{g} / \mathrm{mL}$ for hexane and ethyl acetate) [7]. In the same line, Oueslati et al. 
evaluated the cytotoxic effects of S. fruticosa on Caco-2 and HT29 cell lines [48]. The authors prepared four extracts (hexane, dichloromethane, methanol and water), being the dichloromethane the one that most affects the cells viability $\left(\mathrm{IC}_{50}=140\right.$ and $12 \mu \mathrm{g} / \mathrm{mL}$, respectively, for Caco-2 and HT29 cell lines) [48]. The other extracts of S. fruticosa did not exhibit cytotoxicity [48]. The results reported in the present work ensure that $S$. ramosissima is a safe ingredient for human diet.

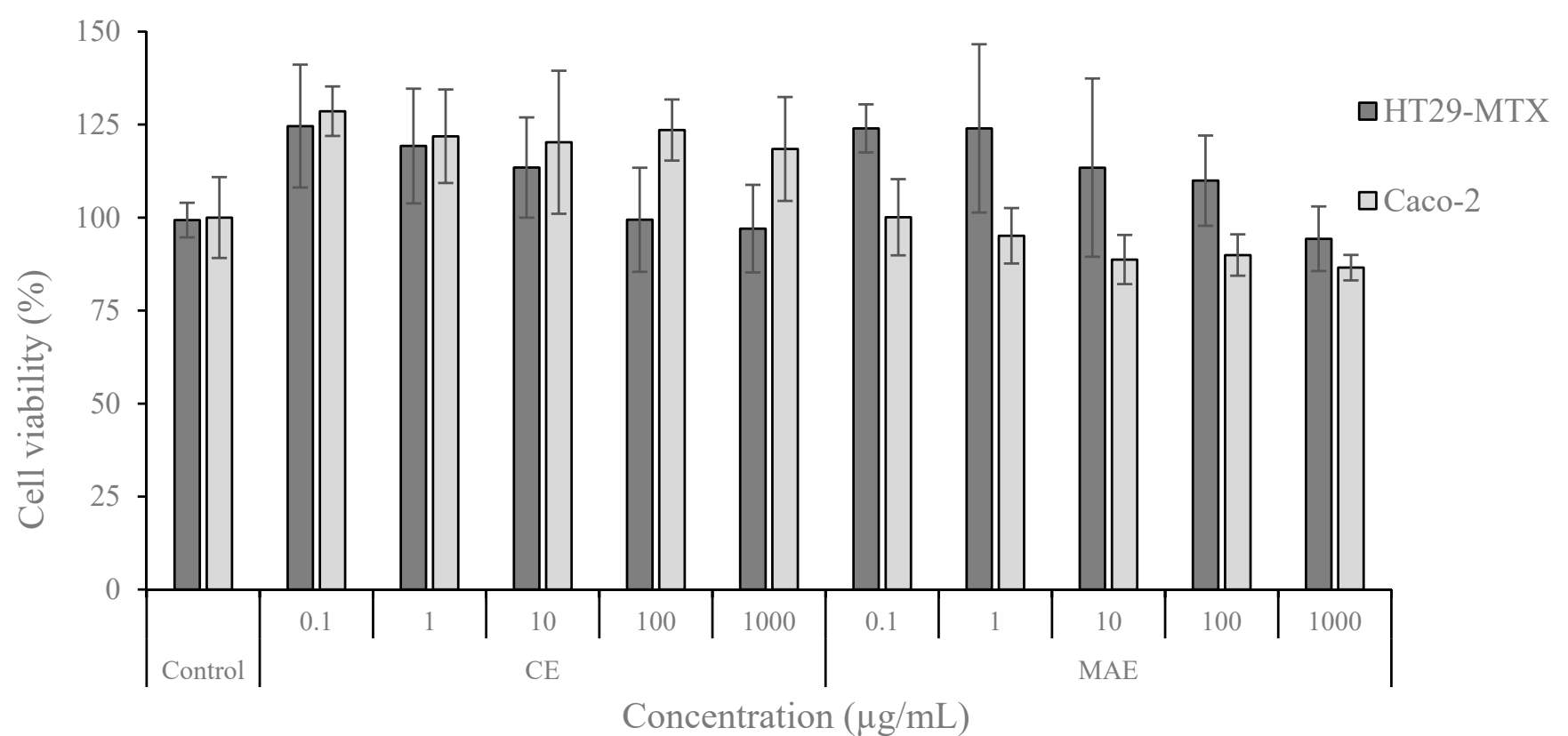

Figure 2. Effects of S. ramosissima extracts prepared by CE and MAE on the viability of HT29-MTX and Caco-2 at a range of concentrations $0.1-1000 \mu \mathrm{g} / \mathrm{mL}$, as measured by the MTT assay $(n=3)$.

\subsection{Organochlorine Pesticides}

Notwithstanding several OCPs have been banned, they can still be detected in food, sediments, plants, animals, and humans [31,50,51]. Despite the long-term monitoring of water quality in the coastal areas of Portugal, the fate of OCP to salt marsh habitats has received little attention. S. ramosissima extracts obtained by CE and MAE were evaluated regarding the presence of 14 organochlorine pesticides. Vestigial levels of $\beta$-endosulfan and $\mathrm{p}, \mathrm{p}^{\prime}$-DDE were detected in the MAE extract. The concentrations levels were in the range of 8-9 ng/g, being 5.5-6 times below their maximum residue levels (MRLs) in Purslanes samples (MRLs $=50 \mathrm{ng} / \mathrm{g}$ ) [52].

To the best of our knowledge, no studies evaluating the presence of pesticides in Portuguese Salicornia were published. However, some authors stated the presence of these compounds in salt marsh habitats (e.g., Salicornia, sediments) in the United States of America (USA) [53], Spain [54] and Argentina [55]. The results obtained confirmed the importance of carrying out these chemical safety studies. Nevertheless, it should be highlighted that the extraction method employed has influence on the results obtained. Besides MAE allow to extract a huge amount bioactive compounds, other compounds such as pesticides may also be obtained. This evaluation allowed to guarantee the chemical safety concerning OCPs for a future application of these extracts in the nutraceutical field.

\section{Conclusions}

The present work was based on the evaluation of S. ramosissima extracts obtained by conventional and MAE techniques, aiming a possible use in the nutraceutical field. The results demonstrated that $S$. ramosissima extracts, especially $\mathrm{CE}$, constitute a good source of bioactive compounds, namely phenolic acids and flavonols. 
CE showed the higher phenolic and flavonoid contents, whereas the highest antioxidant activity was observed in MAE. Regarding the scavenging capacity against ROS, the $\mathrm{CE}$ was the most effective. The phenolic composition of $S$. ramosissima extracts were mainly characterized by the presence of myricetin, gallic acid, catechin, rutin, kaempferol-3-Oglucoside and quercetin-3-O-galactoside, being the phenolic profile very similar between extracts. In what concerns to intestinal cell lines assay, S. ramosissima extracts can be classified as safe once they do not lead to adverse effects on Caco-2 and HT29-MTX cells in concentrations below $1000 \mu \mathrm{g} / \mathrm{mL}$. On the other hand, lower amounts of $\mathrm{p}, \mathrm{p}^{\prime}$-DDE and $\beta$-endosulfan were observed only in the MAE extract. Nevertheless, these levels are still classified as secure by European legislation. Still, it should be highlighted that the evaluation of these compounds is extremely important in samples taken from the aquatic environment.

As a final remake, S. ramosissima extracted by CE or MAE can be classified as non-toxic and rich in bioactive compounds, being suitable for application in the nutraceutical field. Further investigations, such as in-vitro intestinal permeation assays and in-vivo studies, are needed to underline this potential.

Supplementary Materials: The following are available online at https:/ /www.mdpi.com/article/10 $.3390 /$ app11114744/s1, Table S1: Calibration data used for the quantification of individual phenolic compounds in S. ramosissima extracts.

Author Contributions: Conceptualization, F.R.; methodology, A.M.S., M.M.M., D.P., C.G., V.C.F. and F.R.; software, A.M.S., M.M.M., C.G., V.C.F. and F.R.; validation, F.R. and C.D.-M.; formal analysis, A.M.S., M.M.M., C.G., V.C.F. and F.R.; investigation, A.M.S., J.P.L., M.M.M., D.P., C.G., V.C.F. and F.R.; resources, C.D.-M. and F.R.; writing—original draft preparation, A.M.S. and F.R.; writing-review and editing, A.M.S., M.M.M., C.G., V.C.F. and F.R.; visualization, A.M.S., M.M.M., V.C.F., D.P. and F.R.; supervision, F.R.; project administration, F.R.; funding acquisition, C.G., C.D.-M. and F.R. All authors have read and agreed to the published version of the manuscript.

Funding: This research was funded by UIDB/50006/2020 and UIDP/50006/2020 by the Fundação para a Ciência e a Tecnologia (FCT)/Ministério da Ciência, Tecnologia e Ensino Superior (MCTES) through national funds. The authors are also thankful to the project SYSTEMIC "an integrated approach to the challenge of sustainable food systems: adaptive and mitigatory strategies to address climate change and malnutrition", Knowledge hub on Nutrition and Food Security, that has received funding from national research funding parties in Belgium (FWO), France (INRA), Germany (BLE), Italy (MIPAAF), Latvia (IZM), Norway (RCN), Portugal (FCT), and Spain (AEI) in a joint action of JPI HDHL, JPI-OCEANS and FACCE-JPI launched in 2019 under the ERA-NET ERA-HDHL (n 696295).

Institutional Review Board Statement: Not applicable.

Informed Consent Statement: Not applicable.

Data Availability Statement: Data available on request due to restrictions eg privacy or ethical.

Acknowledgments: Ana Margarida Silva (SFRH/BD/144994/2019) and Diana Pinto (SFRH/BD/ 144534/2019) are thankful for the Ph.D. grants from Portuguese Foundation for Science and Technology. Virginia Cruz Fernandes thanks FCT for the financial support through a postdoctoral fellowship (SFRH/BPD/109153/2015). Manuela M. Moreira (CEECIND/02702/2017), Clara Grosso (CEECIND/03436/2020) and Francisca Rodrigues (CEECIND/01886/2020) are thankful for their contracts financed by FCT/MCTES-CEEC Individual Program Contract.

Conflicts of Interest: The authors declare no conflict of interest.

\section{References}

1. Flowers, T.J.; Colmer, T.D. Salinity Tolerance in Halophytes. New Phytol. 2008, 179, 945-963. [CrossRef] [PubMed]

2. Lima, A.R.; Castañeda-Loaiza, V.; Salazar, M.; Nunes, C.; Quintas, C.; Gama, F.; Pestana, M.; Correia, P.J.; Santos, T.; Varela, J.; et al. Influence of Cultivation Salinity in the Nutritional Composition, Antioxidant Capacity and Microbial Quality of Salicornia Ramosissima Commercially Produced in Soilless Systems. Food Chem. 2020, 333, 127525. [CrossRef] [PubMed]

3. Lokhande, V.H.; Suprasanna, P. Prospects of Halophytes in Understanding and Managing Abiotic Stress Tolerance. In Environmental Adaptations and Stress Tolerance of Plants in the Era of Climate Change; Ahmad, P., Prasad, M.N.V., Eds.; Springer: Berlin, Germany, 2012; pp. 29-56. 
4. $\quad$ Barreira, L.; Resek, E.; Rodrigues, M.J.; Rocha, M.I.; Pereira, H.; Bandarra, N.; da Silva, M.M.; Varela, J.; Custódio, L. Halophytes: Gourmet Food with Nutritional Health Benefits? J. Food Comp. Anal. 2017, 59, 35-42. [CrossRef]

5. Ventura, Y.; Sagi, M. Halophyte Crop Cultivation: The Case for Salicornia and Sarcocornia. Environ. Exp. Bot. 2013, 92, 144-153. [CrossRef]

6. $\quad$ Essaidi, I.; Brahmi, Z.; Snoussi, A.; Ben Haj Koubaier, H.; Casabianca, H.; Abe, N.; El Omri, A.; Chaabouni, M.M.; Bouzouita, N. Phytochemical Investigation of Tunisian Salicornia herbacea L., Antioxidant, Antimicrobial and Cytochrome P450 (CYPs) Inhibitory Activities of Its Methanol Extract. Food Control 2013, 32, 125-133. [CrossRef]

7. Kang, S.; Kim, D.; Lee, B.H.; Kim, M.R.; Hong, J.; Chiang, M. Antioxidant Properties and Cytotoxic Effects of Fractions from Glasswort (Salicornia herbacea) Seed Extracts on Human Intestinal Cells. Food Sci. Biotechnol. 2011, 20, 115-122. [CrossRef]

8. Szymańska, S.; Borruso, L.; Brusetti, L.; Hulisz, P.; Furtado, B.; Hrynkiewicz, K. Bacterial Microbiome of Root-associated Endophytes of Salicornia europaea in Correspondence to Different Levels of Salinity. Environ. Sci. Pollut. Res. Int. 2018, 25, 25420-25431. [CrossRef]

9. Sung, J.-H.; Park, S.-H.; Seo, D.-H.; Lee, J.-H.; Hong, S.-W.; Hong, S.-S. Antioxidative and Skin-Whitening Effect of an Aqueous Extract of Salicornia herbacea. Biosci. Biotechnol. Biochem. 2009, 73, 80601-80602. [CrossRef]

10. Ferreira, D.; Pinto, D.C.G.A.; Silva, H.; Girol, A.P.; de Lourdes Pereira, M. Salicornia ramosissima J. Woods Seeds Affected the Normal Regenerative Function on Carbon Tetrachloride-induced Liver and Kidney Injury. Biomed. Pharmacother. 2018, 107, 283-291. [CrossRef]

11. Davy, A.J.; Bishop, G.F.; Costa, C.S.B. Salicornia L.(Salicornia pusilla J. Woods, S. ramosissima J. Woods, S. europaea L., S. obscura PW Ball \& Tutin, S. nitens PW Ball \& Tutin, S. fragilis PW Ball \& Tutin and S. dolichostachya moss). J. Ecol. 2001, 89, 681-707.

12. Silva, H.; Caldeira, G.; Freitas, H. Salicornia ramosissima Population Dynamics and Tolerance of Salinity. Ecol. Res. 2007, 22, 125-134. [CrossRef]

13. Panja, P. Green Extraction Methods of Food Polyphenols from Vegetable Materials. Curr. Opin. Food Sci. 2018, $23,173-182$. [CrossRef]

14. Saini, A.; Panesar, P.S. Beneficiation of Food Processing by-products through Extraction of Bioactive Compounds Using Neoteric Solvents. LWT Food Sci. Technol. 2020, 134, 110263. [CrossRef]

15. Eskilsson, C.S.; Björklund, E. Analytical-scale Microwave-assisted Extraction. J. Chromatogr. A 2000, 902, 227-250. [CrossRef]

16. Leyva-Jiménez, F.J.; Lozano-Sánchez, J.; Borrás-Linares, I.; Arráez-Román, D.; Segura-Carretero, A. Manufacturing Design to Improve the Attainment of Functional Ingredients from Aloysia citriodora Leaves by Advanced Microwave Technology. J. Ind. Eng. Chem. 2019, 79, 52-61. [CrossRef]

17. Moreira, M.M.; Barroso, M.F.; Boeykens, A.; Withouck, H.; Morais, S.; Delerue-Matos, C. Valorization of Apple Tree Wood Residues by Polyphenols Extraction: Comparison between Conventional and Microwave-assisted Extraction. Ind. Crop. Prod. 2017, 104, 210-220. [CrossRef]

18. Moreira, M.M.; Barroso, M.F.; Porto, J.V.; Ramalhosa, M.J.; Švarc-Gajić, J.; Estevinho, L.; Morais, S.; Delerue-Matos, C. Potential of Portuguese Vine Shoot Wastes as Natural Resources of Bioactive Compounds. Sci. Total Environ. 2018, 634, 831-842. [CrossRef] [PubMed]

19. Pimentel-Moral, S.; Borrás-Linares, I.; Lozano-Sánchez, J.; Arráez-Román, D.; Martínez-Férez, A.; Segura-Carretero, A. Microwaveassisted extraction for Hibiscus sabdariffa bioactive compounds. J. Phar. Biomed. Anal. 2018, 156, 313-322. [CrossRef]

20. Valdés, B.; Castroviejo, S. Flora Iberica. Plantas Vasculares de la Península Ibérica e Islas Baleares; Castroviejo, S., Laínz, M., López González, G., Montserrat, P., Munõz Garmendia, F., Paiva, J., Villar, L., Eds.; Real Jardín Botánico, CSIC: Madrid, Spain, 1990; Volume 2, pp. 531-534.

21. Silva, A.M.; Pinto, D.; Fernandes, I.; Freitas, V.D.; Cádiz-Gurrea, M.D.L.L.; Costa, P.; Delerue-Matos, C.; Rodrigues, F. An Insight into Kiwiberry Leaf Valorization: Phenolic Composition, Bioactivity and Health Benefits. Molecules 2021, 26, 2314. [CrossRef]

22. Singleton, V.L.; Rossi, J.A. Colorimetry of Total Phenolics with Phosphomolybdic-Phosphotungstic Acid Reagents. Am. J. Enol. Vit. 1965, 16, 144-158.

23. Pinto, D.; Vieira, E.F.; Peixoto, A.F.; Freire, C.; Freitas, V.; Costa, P.; Delerue-Matos, C.; Rodrigues, F. Optimizing the Extraction of Phenolic Antioxidants from Chestnut Shells by Subcritical Water Extraction Using Response Surface Methodology. Food Chem. 2021, 334, 127521. [CrossRef] [PubMed]

24. Rodrigues, F.; Palmeira-de-Oliveira, A.; das Neves, J.; Sarmento, B.; Amaral, M.H.; Oliveira, M.B. Medicago spp. Extracts as Promising Ingredients for Skin Care Products. Ind. Crop. Prod. 2013, 49, 634-644. [CrossRef]

25. Benzie, I.F.F.; Strain, J.J. Ferric Reducing/Antioxidant Power Assay: Direct Measure of Total Antioxidant Activity of Biological Fluids and Modified Version for Simultaneous Measurement of Total Antioxidant Power and Ascorbic Acid Concentration. Methods Enzymol. 1999, 299, 15-27.

26. Re, R.; Pellegrini, N.; Proteggente, A.; Pannala, A.; Yang, M.; Rice-Evans, C. Antioxidant Activity Applying an Improved ABTS Radical Cation Decolorization Assay. Free Radic. Biol. Med. 1999, 26, 1231-1237. [CrossRef]

27. Pinto, D.; Cádiz-Gurrea, M.D.L.L.; Sut, S.; Ferreira, A.S.; Leyva-Jimenez, F.J.; Dall'acqua, S.; Segura-Carretero, A.; Delerue-Matos, C.; Rodrigues, F. Valorisation of Underexploited Castanea sativa Shells Bioactive Compounds Recovered by Supercritical Fluid Extraction with $\mathrm{CO}_{2}$ : A Response Surface Methodology Approach. J. CO 2 Util. 2020, 40, 101194. [CrossRef]

28. Gomes, A.; Fernandes, E.; Silva, A.M.S.; Santos, C.M.M.; Pinto, D.C.G.A.; Cavaleiro, J.A.S.; Lima, J.L.F.C. 2-Styrylchromones: Novel Strong Scavengers of Reactive Oxygen and Nitrogen Species. Bioorg. Med. Chem. 2007, 15, 6027-6036. [CrossRef] [PubMed] 
29. Ou, B.; Hampsch-Woodill, M.; Prior, R.L. Development and Validation of an Improved Oxygen Radical Absorbance Capacity Assay Using Fluorescein as the Fuorescent Probe. J. Agric. Food Chem. 2001, 49, 4619-4626. [CrossRef] [PubMed]

30. De Francisco, L.; Pinto, D.; Rosseto, H.; Toledo, L.; Santos, R.; Tobaldini-Valério, F.; Svidzinski, T.; Bruschi, M.; Sarmento, B.; Oliveira, M.B.P.P.; et al. Evaluation of Radical Scavenging Activity, Intestinal Cell Viability and Antifungal Activity of Brazilian Propolis by-product. Food Res. Int. 2018, 105, 537-547. [CrossRef]

31. Lobato, A.; Fernandes, V.C.; Pacheco, J.G.; Delerue-Matos, C.; Gonçalves, L.M. Organochlorine Pesticide Analysis in Milk by Gas-diffusion Microextraction with Gas Chromatography-electron Capture Detection and Confirmation by Mass Spectrometry. J. Chromatogr. A 2021, 1636, 461797. [CrossRef]

32. Medini, F.; Bourgou, S.; Lalancette, K.; Snoussi, M.; Mkadmini, K.; Coté, I.; Abdelly, C.; Legault, J.; Ksouri, R. Phytochemical Analysis, Antioxidant, Anti-inflammatory, and Anticancer Activities of the Halophyte Limonium densiflorum Extracts on Human Cell Lines and Murine Macrophages. S. Afr. J. Bot. 2015, 99, 158-164. [CrossRef]

33. Jallali, I.; Zaouali, Y.; Missaoui, I.; Smeoui, A.; Abdelly, C.; Ksouri, R. Variability of Antioxidant and Antibacterial Effects of Essential Oils and Acetonic Extracts of Two Edible Halophytes: Crithmum maritimum L. and Inula crithmoïdes L. Food Chem. 2014, 145, 1031-1038. [CrossRef] [PubMed]

34. Silva, A.M.; Pinto, D.; Fernandes, I.; Gonçalves Albuquerque, T.; Costa, H.S.; Freitas, V.; Rodrigues, F.; Oliveira, M.B.P.P. Infusions and Decoctions of Dehydrated Fruits of Actinidia arguta and Actinidia deliciosa: Bioactivity, Radical Scavenging Activity and Effects on Cells Viability. Food Chem. 2019, 289, 625-634. [CrossRef] [PubMed]

35. Costa, C.; Padalino, L.; Spinelli, S.; Serio, F.; Del Nobile Matteo, A.; Conte, A. Study of the Efficacy of Two Extraction Techniques from Crithmum maritimum and Salicornia europaea. J. Food Nutr. Res. 2018, 6, 456-463.

36. Semwal, D.K.; Semwal, R.B.; Combrinck, S.; Viljoen, A. Myricetin: A Dietary Molecule with Diverse Biological Activities. Nutrients 2016, 8, 90. [CrossRef] [PubMed]

37. Song, X.; Tan, L.; Wang, M.; Ren, C.; Guo, C.; Yang, B.; Ren, Y.; Cao, Z.; Li, Y.; Pei, J. Myricetin: A Review of the most Recent Research. Biomed. Pharmacother. 2021, 134, 111017. [CrossRef]

38. Taheri, Y.; Suleria, H.A.R.; Martins, N.; Sytar, O.; Beyatli, A.; Yeskaliyeva, B.; Seitimova, G.; Salehi, B.; Semwal, P.; Painuli, S. Myricetin Bioactive Effects: Moving from Preclinical Evidence to Potential Clinical Applications. BMC Complement. Med. Ther. 2020, 20, 1-14. [CrossRef]

39. Park, S.; Song, G.; Lim, W. Myricetin Inhibits Endometriosis Growth through Cyclin E1 Down-regulation In Vitro and In Vivo. J. Nutr. Biochem. 2020, 78, 108328. [CrossRef]

40. Zengin, G.; Aumeeruddy-Elalfi, Z.; Mollica, A.; Yilmaz, M.A.; Mahomoodally, M.F. In Vitro and In Silico Perspectives on Biological and Phytochemical Profile of Three Halophyte Species-A Source of Innovative Phytopharmaceuticals from Nature. Phytomedicine 2018, 38, 35-44. [CrossRef]

41. Bertin, R.L.; Gonzaga, L.V.; Borges, G.D.S.C.; Azevedo, M.S.; Maltez, H.F.; Heller, M.; Micke, G.A.; Tavares, L.B.B.; Fett, R. Nutrient Composition and, Identification/Quantification of Major Phenolic Compounds in Sarcocornia ambigua (Amaranthaceae) Using HPLC-ESI-MS/MS. Food Res. Int. 2014, 55, 404-411. [CrossRef]

42. Bose, J.; Rodrigo-Moreno, A.; Shabala, S. ROS Homeostasis in Halophytes in the Context of Salinity Stress Tolerance. J. Exp. Bot. 2014, 65, 1241-1257. [CrossRef]

43. Robak, J.; Gryglewski, R.J. Flavonoids are Scavengers of Superoxide Anions. Biochem. Pharmacol. 1988, 37, 837-841. [CrossRef]

44. Daffodil, E.D.; Rajalakshmi, K.; Mohan, V.R. Antioxidant Activity, Total Phenolics and Flavonoids of Salicornia brachiata Roxb. Leaf Extracts (Chenopodiaceae). World J. Pharm. Pharm. Sci. 2013, 2, 352-366.

45. Roschek, B.; Tallman, K.A.; Rector, C.L.; Gillmore, J.G.; Pratt, D.A.; Punta, C.; Porter, N.A. Peroxyl Radical Clocks. J. Org. Chem. 2006, 71, 3527-3532. [CrossRef] [PubMed]

46. Dugas, A.J., Jr.; Castañeda-Acosta, J.; Bonin, G.C.; Price, K.L.; Fischer, N.H.; Winston, G.W. Evaluation of the Total Peroxyl Radical-scavenging Capacity of Flavonoids: Structure-Activity Relationships. J. Nat. Prod. 2000, 63, 327-331. [CrossRef]

47. Souid, A.; Bellani, L.; Magné, C.; Zorrig, W.; Smaoui, A.; Abdelly, C.; Longo, V.; Hamed, K.B. Physiological and Antioxidant Responses of the Sabkha Biotope Halophyte Limonium delicatulum to Seasonal Changes in Environmental Conditions. Plant Physiol. Biochem. 2018, 123, 180-191. [CrossRef] [PubMed]

48. Oueslati, S.; Ksouri, R.; Falleh, H.; Pichette, A.; Abdelly, C.; Legault, J. Phenolic Content, Antioxidant, Anti-inflammatory and Anticancer Activities of the Edible Halophyte Suaeda fruticosa Forssk. Food Chem. 2012, 132, 943-947. [CrossRef]

49. Trujillo-Rodríguez, M.J.; Rosende, M.; Miró, M. Combining In Vitro Oral Bioaccessibility Methods with Biological Assays for Human Exposome Studies of Contaminants of Emerging Concern in Solid Samples. TrAC Trends Anal. Chem. 2020, 132, 116040. [CrossRef]

50. Pestana, D.; Faria, G.; Sá, C.; Fernandes, V.C.; Teixeira, D.; Norberto, S.; Faria, A.; Meireles, M.; Marques, C.; Correia-Sá, L. Persistent Organic Pollutant Levels in Human Visceral and Subcutaneous Adipose Tissue in Obese Individuals-Depot Differences and Dysmetabolism Implications. Environment. Res. 2014, 133, 170-177. [CrossRef] [PubMed]

51. Maia, M.L.; Sousa, S.; Correia-Sá, M.L.; Delerue-Matos, C.; Calhau, C.; Domingues, V.F. Organochlorine Pesticides, Brominated Flame Retardants, Synthetic Musks and Polycyclic Aromatic Hydrocarbons in Shrimps. An Overview of Occurrence and Its Implication on Human Exposure. Heliyon 2020, 6, e04870. [CrossRef] [PubMed] 
52. Parliament, E. REGULATION (EC) NO 396/2005 of the European pParliament and of the Council of 23 February 2005 on Maximum Residue Levels of Pesticides in or on Food and Feed of Plant and Animal Origin and Amending Council Directive 91/414/EEC. Off. J. Eur. Union 2005, 16, 1-16.

53. Masters, P.M.; Inman, D.L. Transport and Fate of Organochlorines Discharged to the Salt Marsh at Upper Newport Bay, California, USA. Environ. Toxicol. Chem. 2000, 19, 2076-2084. [CrossRef]

54. Sánchez-Palencia, Y.; Ortiz, J.E.; Torres, T.; Llamas, J. Organochlorine Pesticides in Protected Areas: El Hito Lake (Cuenca, Central Spain). J. Iber. Geol. 2017, 43, 539-557. [CrossRef]

55. Commendatore, M.; Yorio, P.; Scenna, L.; Ondarza, P.M.; Suárez, N.; Marinao, C.; Miglioranza, K.S. Persistent Organic Pollutants in Sediments, Intertidal Crabs, and the Threatened Olrog's Gull in a Northern Patagonia Salt Marsh, Argentina. Mar. Pollut. Bull. 2018, 136, 533-546. [CrossRef] [PubMed] 